Dossiê

\title{
Tecendo o mundo e as origens da vida como a conhecemos: noções de crescimento, fabricação e reprodução nos mitos de origem yukpa
}

Weaving the world and the origins of life as we know it: notions of growth, fabrication and reproduction in Yukpa origin myths

Ernst Halbmayer

Marburg University, Alemanha ernst.balbmayen@staff.uni-marburg.de

RESUMO: Este artigo aborda o sentido da vida entre os Yukpa tal como descrito e verbalizado em seus mitos de origem. Os mitos yukpa transmitem conhecimentos particularmente conceitualizados sobre os processos vitais, em parte concebidos como uma forma de arte que requer grande habilidade, e sobre as transformaçóes que criam as condiçôes e as formas da vida como a conhecemos. Ao focalizar os processos que criam a vida como ela é conhecida hoje, os processos vitais do crescimento, da fabricação e da reprodução são identificados e diferenciados. Argumenta-se que os processos vitais entre os Yukpa ultrapassam a reprodução biológica e autorreferenciada das diferentes espécies, e também as atividades instrumentais da fabricação. A vida é conceitualizada seja como uma atividade relacional espacializada e continuamente localizada, seja como transformaçóes metamórficas cíclicas. Da perspectiva localizada, que consiste em sair ou desaparecer de uma atividade relacional, estão as formas de morrer ou nascer. A vida nesse sentido metamórfico inclui a existência continuada em mundos coexistentes. Um fim definitivo da vida ocorrerá apenas se estas transformaçóes metamórficas e cíclicas chegarem a um termo. 
PALAVRAS-CHAVE: Yukpa, mitos de origem, processos-vitais, habilidade, fabricação, crescimento, reprodução, vida como uma atividade relacional localizada, vida como transformação metamórfica cíclica.

Este artigo aborda o sentido e o surgimento da vida entre os Yukpa tais como retratados em seus mitos de origem ${ }^{1}$. Ele começa pela questão de como vieram a existir os seres vivos e as condiçóes propícias à vida no mundo, focando os processos que criam a vida tal como a conhecemos hoje. A análise se inicia pelo papel dos mitos na compreensão das concepçôes de vida, identificando e diferenciando os processos vitais de crescimento $^{2}$, fabricação e reprodução. As narraçóes mitológicas entre os Yukpa não lidam com as origens da vida, mas representam e transmitem conhecimentos particularmente conceitualizados e explicaçóes verbalizadas sobre os processos vitais, em parte concebidos como uma forma de arte que requer grande habilidade, e também com as transformaçôes que criam as condiçóes e formas da vida tal como a conhecemos.

Evidentemente, tal foco no conhecimento conceitualizado contrasta com abordagens fenomenológicas que enfatizam as percepçóes e experiências vividas pré-conceituais (como em Ingold, 2011). Um foco nos mitos necessariamente se concentrará em conceitos verbalizados, com maior ênfase nas explicações que nas percepçóes sensíveis e na imersão generalizada daqueles que crescem e produzem em seu próprio ambiente. Observar as narraçóes de mitos oferece, mais do que isso, a oportunidade de investigar e reconhecer formas de objetivação da vida diferentemente articuladas, e os princípios nos quais se baseiam os viventes e as diferentes formas de vida (Pitrou, 2014) ${ }^{3}$. As explicações mitológicas formam, ao mesmo tempo, uma parte intrínseca da percepção e das práticas diárias, na medida em que postulam e afirmam os princípios básicos de entendimento, exemplificando aspectos do mundo normalmente invisíveis e imperceptíveis, e explicando transformaçôes, que incluem também os eventos históricos ${ }^{4}$, além de demonstrar consequências do comportamento humano. Sob esta perspectiva, não são as percepções pré-objetivas ou pré-éticas, mas as formas de objetificação e conceitualização que ganham foco 5 . No exemplo a seguir, torna-se visível um espectro diferenciado de atividades que contribui para a criação da vida tal como a conhecemos hoje. A fabricação e o fazer exercem aí um papel importante e estão relacionadas de formas específicas - mas não idênticas - ao crescimento e à reprodução (Pitrou, 2015). 
O resultado deste exercício, como ficará claro, levanta dúvidas quanto a uma prioridade ontológica do crescer sobre o fazer na perspectiva yukpa. O crescimento não necessariamente se torna "a forma de devir por meio da qual as formas do artificial se configuram" (Hallam e Ingold, 2015: 5), mas questiona também o argumento inverso, avançado por Fernando Santos-Granero (2009), que identificou, na Amazônia, diferentes regimes de objetos e argumentou a favor de um quadro simbólico comum acerca da fabricação. A fabricação abrange a distinção entre pessoas e coisas e ele considera a confecção, que "dá o modelo de todos os atos criativos", como anterior à procriação sexual (2009: 8). Apesar destes insights, a noção de fabricação proposta por Santos-Granero permanece uma "caixa preta" teórica, cujo conteúdo desconhecemos, assim como as formas que pode assumir ${ }^{6}$. O experimento que realizarei a seguir consiste em perguntar quais formas de crescer, fabricar e reproduzir a vida podem ser encontradas nos mitos de origem yukpa, com base nas formas verbais e linguísticas empregadas para descrever estas atividades.

Nos mitos yukpa, imagens sonoras ocupam um lugar proeminente nas narraçóes verbalizadas. Elas podem ser ícones, que desconhecem a diferença entre o símbolo e o objeto a que ele se refere, ou índices, que indicam algo que não está representado, como demonstrou Kohn (2013) para os Napo Runa. A despeito da importância das imagens sonoras nas narraçóes míticas, assim como nas interaçóes com seres não-humanos que ocorrem na vida real, seu papel não é o mesmo nas duas áreas. Nos mitos yukpa, as imagens sonoras (tanto os ícones quanto os índices) não são indicaçôes de atores não-humanos, mas, de modo mais geral, expressam ação, transformação e mudança. Elas fazem com que as narraçóes se tornem vivazes e são empregadas de uma maneira comparável, em linhas gerais, aos símbolos sonoros nos quadrinhos. A maior parte da comunicação presente nos mitos, seja ela de humanos, espíritos e animais entre si, ou uns com os outros, é representada de forma literal - e, portanto, simbólica - e, frequentemente, por meio do discurso direto, citado diretamente. Em contraste com as interaçóes quotidianas com não-humanos, sua representação não se apoia em uma "ecologia da vida para além do humano" (Kohn, 2007, 2013) baseada em signos não-simbólicos tais como ícones e índices (Kohn, 2007, 2013). Nos mitos, animais, espíritos e heróis culturais são, assim como os humanos, conhecedores do uso de signos simbólicos e da fala. Os mitos explicam como esta situação mudou e como surgiu a vida tal como é conhecida hoje. Ao observar os processos vitais nos mitos Yukpa, 
alguém poderia, entretanto, questionar se o uso comum de signos simbólicos e, portanto, a cultura, é um critério suficiente para uma indiferenciação mítica entre animais e humanos. Seriam os animais realmente ex-humanos, como argumentou Viveiros de Castro (1998), ou teriam eles se tornado os animais contemporâneos exatamente porque eles não eram plenamente humanos?

O sentido dos mitos não é apenas representado em atos de fala verbalizados e em símbolos sonoros. Uma narração mítica revela seu sentido na relação com sua performance, incluindo os gestos do narrador e a experiência vivida da audiência. Seu sentido se desdobra não apenas em relação a outros mitos, mas também em relação ao ambiente, à paisagem e aos seres que a habitam. Ele emerge em relação a objetos manufaturados, e em relação a rituais e práticas sociais. "Não é possível para os seres humanos", como escrevem Uzendoski e Capalpucha-Tapuy, "viver em mundos puramente 'orais', mundos sem inscrição e textualidade" (2012: 9). Não é necessário que tais inscriçôes tomem a forma da escrita alfabética. Elas podem ocorrer por meio da tessitura (ver Guss, 1989 e van Velthem, 1992, 1998), da memorização pictográfica (Severi, 2015), de desenhos (Lagrou, 2012), da construção de uma casa (Barándiaran, 1966 e Halbmayer, 2010), da caça (Århem, 1996) ou pela abertura e plantio de uma roça. O mito está, pois, inscrito em práticas, lugares (Santos-Granero, 1998, 2004 e Halbmayer, 2004a), objetos e corpos (Uzendoski, 2012 e Fortis, 2014). E o sentido, dessa maneira, não emerge apenas por meio da fala verbalizada, mas também por meio das relaçóes, das similaridades e das diferenças, entre as açóes retratadas nas narrativas e as práticas e observações cotidianas. Essas diferenças perceptíveis que fazem uma diferença ${ }^{7}$ são assim não apenas sons, barulhos ou indicações de mudanças naturais, mas podem ser percebidas como signos proferidos por seres não-humanos copresentes, mas invisíveis. Tais elocuçôes podem se manifestar na neblina, nos raios, em um terremoto, no comportamento de animais ou em sonhos. Mitos podem também ser inscritos em lugares que por sua vez tornam-se signos visíveis de eventos mitológicos passados. Essas formas de representação, comunicação e textualidade ultrapassam as fronteiras do oral e do escrito, do humano e do não-humano e do social e natural. É neste sentido relacional, baseado na capacidade de se inscrever em outras formas textuais, que os mitos se tornam - como Malinowski certa vez argumentou - "não apenas uma estória contada, mas uma realidade vivida" (1948 [1926]: 100). 
Enquanto o sentido emerge da relação entre as palavras faladas e as práticas e percepçóes cotidianas, a performance de um mito náo estabelece uma relaçáo interacional vivida com outros seres. Os mitos retratam e representam a interação e o intercâmbio entre seres diferentes, mas eles não são - ao menos entre os Yukpa - uma via ou ferramenta para se realizar um tal intercâmbio. Pelo contrário, o ato de narrar um mito cria uma situação extraordinária, na medida em que elimina temporariamente a sempre presente possibilidade de comunicação trans-específica. Narrar o mito da jornada à terra dos mortos náo implica entrar em contato com os espíritos dos mortos. Quem conta um mito sobre os seres subaquáticos ou celestiais não estabelece contato com aqueles cujas ações são descritas nos mitos. Nem o narrador, nem sua audiência se transformarão em um jaguar ou em uma sucuri. Mito não é ritual, sonho ou ação xamânica. Ao discutir e representar, os mitos, ao invés disso, abolem temporariamente a possibilidade de interação com seres náo-humanos. Açóes cotidianas trazem em si mesmas mais opçóes de contato direto (consciente ou inconsciente) com seres não-humanos que quando um mito é contado. Apesar de Lévi-Strauss ter comparado a composição estrutural dos mitos à da música, a música, que é a linguagem preferida pelos ameríndios para a comunicação com os espíritos (Brabec, 2012), não é mito. Essa ausência de relacionalidade interativa para além do público humano indica também que esses seres são incapazes de compreender a língua falada dos mitos. As narraçóes, por meio de sua própria discursividade, estabelecem durante sua realização uma representação verbalizada temporária que lhes é própria.

\section{Os Yukpa e seus mitos de origem}

Os Yukpa representam um bastiáo contemporâneo, a noroeste, dos ameríndios falantes de língua caribe. Eles vivem tanto no lado venezuelano quanto no lado colombiano da Sierra de Perijá, ao sul dos Wayuu, falantes de arawak, ao sudeste dos grupos falantes de chibcha da Sierra Nievada e de Santa Marta (Kogi, Arhuaco, Wiwa e Kankuama) e ao norte dos Barí, que também falam uma língua chibcha. Esta é uma região na qual confluem influências andinas, amazônicas e mesoamericanas. E os Yukpa, um grupo falante de caribe que penetrou uma regiấo diversamente categorizada como uma área chibcha (Kirchhoff, 
1943), zona intermediária (Haberland, 1957) ou como uma área istmo-colombiana (Hoopes e Fonseca, 2003), se adaptaram a ela de modo seletivo.

Subgrupos yukpa distintos habitam vários vales fluviais situados na Sierra de Perijá (ver Halbmayer, 2013b). Eles falam dialetos diferentes e suas tradiçóes orais possuem variaçóes acentuadas em seus detalhes. Estas são mais bem compreendidas como versóes transformacionais de temas e estruturas míticas comuns que complementam e esclarecem uns aos outros. A seguir, vou me referir a dados coletados entre três dos subgrupos yukpa: os Irapa venezuelanos entre os quais trabalhei em diversas ocasióes no período que vai de 1991 a 2009, os Iroka colombianos onde realizei trabalhos de campo certo número de vezes entre 2009 e 2014 e os Sokorpa colombianos entre os quais fiz pesquisa mais recentemente em 2014. Em cada caso mencionarei de qual grupo os detalhes etnográficos e nomes derivam, e empregarei - a não ser que seja mencionado de outra forma - uma transcrição do dialeto Iroka, uma vez que a narração principal da qual retirarei as passagens citadas é um mito Iroka. Dito isto, apesar da aproximação de informaçóes complementares de diferentes grupos possibilitar a emergência de uma meta-reflexão, ela dificilmente fará justiça a cada versão particular das variantes locais.

Em termos gerais, há quatro complexos mitológicos centrais que lidam com a transformação do mundo e a criação das formas de vida como os Yukpa a conhecem hoje. Uma primeira série de narraçóes aborda a criação e a transformação deste mundo e o estabelecimento da vida humana e animal. A série seguinte - uma versão do mito dos gêmeos -, descreve como o céu noturno foi povoado e explica as mudanças sazonais entre as estações secas e chuvosas. Por fim, uma terceira série de narrativas aborda a origem das plantas cultivadas, especialmente o milho, enquanto uma quarta lida com os brancos e sua tecnologia. Focarei o primeiro complexo de mitos mencionado, nos quais um herói cultural chamado Amoricha [Irapa] ou Otompa [Iroka] desce à terra, transformando o mundo e criando a vida animal e a vida humana tal como as conhecemos hoje. Nos dias de hoje esse herói cultural também é referido como Maipore [Irapa], Aponto [Iroka, Sokorpa] ou Papsh tyos, isto é, Deus-pai. Estes termos se referem também ao Deus cristão e indicam que o herói cultural mítico e o Deus cristão são considerados hoje por muitos Yukpa como um e o mesmo.

Estas narraçôes são entendidas pelos Yukpa como explicações válidas de como os modos de existência e seres contemporâneos vieram a ser, como o mundo tomou sua forma atual e quais regras devem ser respeitadas de modo a manter na terra as condiçóes de vida 
equilibradas que foram estabelecidas por esses processos. Enquanto as versões dos Irapa e, em alguma medida, dos Sokorpa, ressaltam como as condições hostis à vida no mundo se transformaram em condiçóes equilibradas e propícias a ela, tornando-a possível, os Iroka por sua vez enfatizam como elementos básicos deste mundo passaram a existir e como a reprodução se tornou possível. Entretanto - e interessantemente -, em todos esses mitos os termos para "estar vivo", oshepa (um adjetivo derivado de shepa - isto é, verde, como uma madeira ou planta verde) ou "viver", osesapa [os - rfl. estar vivendo ou residindo em algum lugar] não são mencionados.

Esses mitos não estáo refletindo sobre a questão de estar vivo ou não, de viver ou nãoviver, mas lidam com a formação e transformação das formas e condiçôes de vida. Por meio dessas transformações, condiçôes específicas e formas de existência são estabelecidas na terra e as noçóes de viver, nascer e morrer serão reconsideradas nesse contexto. Não há um único mito que eu conheça no qual objetos se transformem em humanos ou ajam por conta própria. Assim, as atividades do herói cultural estabelecem um "quadro simbólico de fabricação" comum no qual não é a fabricação de artefatos que é importante, mas a "fabricação" do mundo e dos seres vivos enquanto tais. Fazer a vida como a conhecemos equivale a iniciar transformaçóes significantes. Ao mesmo tempo, o mito afirma que a fabricação é necessária, mas permite apenas formas de reprodução incompletas, não autorreprodutivas.

Amoricha, como os Irapa chamam seu herói cultural, é uma expressão condensada desta observação. Múltiplas referências e analogias associam esse ser mítico a diferentes níveis de significado. Etimologicamente, o termo Amoricha deriva do verbo -amó-, que significa construir uma casa ${ }^{8}$ ou mais basicamente um invólucro; do marcador de posse que atua como nominalizador ri-; e do sufixo humanizante -cha, que indica uma pessoa falecida. Dessa forma, Amoricha pode ser traduzido como a pessoa já falecida que possuía [o conhecimento para ou a capacidade de] fazer ou construir. O termo indica que esse ser não está associado com uma força geradora de vida'. Mais que isso, Amoricha é aquele que constrói e fabrica as formas de vida tal como as conhecemos hoje. Ele não está criando a vida em si mesma, já que não há criação ex nihilo entre os Yukpa. Há vida antes que as atividades transformativas do herói cultural tenham se iniciado ${ }^{10}$ e há, como mostrei recentemente em uma discussão sobre rituais mortuários yukpa (Halbmayer, 2013a), formas bastante elaboradas de vida até mesmo após a morte fisiológica. A vida é desprovida tanto de um início quanto de um final absolutos, quer falemos de pessoas individuais ou do 
mundo, mas há transformaçóes radicais e significantes, além de mudanças que tornaram possíveis as formas e condiçóes específicas da vida como a conhecemos hoje; viver, nascer e morrer como o fazem plantas, animais ou pessoas humanas, deve ser entendido neste contexto. Esta situaçáo aparentemente contraditória, na qual alguém pode morrer sem que haja um início ou um final absoluto da vida irá, assim espero, tornar-se mais clara após observarmos mais de perto as articulaçôes da vida nos mitos de origem yukpa.

O espaço-tempo no qual as atividades de Amoricha tiveram lugar é chamado owaya tamoiya, o tempo em que o mundo estava em construção, isto é, um tempo original e hipertransformativo comumente referido também como misterioso. Hoje, na medida em que o herói cultural é associado e está parcialmente fundido com o Deus cristão, os Yukpa tendem a associar de forma mais ou menos livre o tempo original do owaya tamoiya com o Gênesis cristão. Entretanto, tendo em vista possíveis mudanças perigosas no mundo, como experienciadas durante a seca excepcional ocorrida em 2014 ou durante um eclipse (ver Halbmayer, 2004b), os Yukpa temem o retorno deste tempo-espaço original e a volta de suas condições desequilibradas na terra.

\section{A origem como metamorfose: deixando o abrigo}

Logo ao início, o mito iroka menciona que o herói cultural existia só, para si mesmo, twapa, termo composto pelo infinitivo de verbos intransitivos $t w$-, pelo verbo ser [-a-] e pelo sufixo humanizante - $p a$. A narrativa começa da seguinte maneira ${ }^{11}$ :

O Deus-pai estava existindo sozinho [twapa]. Naquele tempo, o Deus-pai era um casulo [monseno]... De lá ele desceu com seu fio de seda, de lá do mundo [owaya] de cima. Dalí ele estava costurando, o Deus-pai. A mãe do Deus-pai [era uma] aranha, por isso seu nome era aranha [achhaya]. [Com o] fio de seda, ele desceu até aqui, vindo de lá de cima. Então o Deus-pai era um casulo. Quando o Deus-pai era um casulo ele saiu [netokanako] dele, o Deus-pai. Então ele saiu de sua capa de pele [yusĉhtt]. Lá, o casulo era sua capa de pele. Ele se partiu no meio [em dois]. Para baixo ele foi, em direção a esta terra [nono]. Lá em cima [está o outro] mundo. De lá ele desceu, o Deus-pai. Então o Deus-pai cresceu [natának]. Ele se endireitou na terra [nztkzntanak]. Toda a sua capa de pele virou terra. Lá ele se endireitou. Assim foi, e o Deus-pai disse: "Não, esta terra é pequena", ele disse. Imediatamente [ele teve o] desejo, e falou novamente. Ampla ela estava se 
transformando, ampla ele estava transformando [nachhopnak] a terra. A terra era pequena. Ampla ele estava transformando a terra. Ampla ela estava se transformando ${ }^{12}$.

Observemos mais de perto esta sequência inicial, à qual retornarei na parte final do artigo. Ela afirma que Deus era um ser vivo, o filho de uma aranha, que vivia em um casulo, evidentemente em um estado de metamorfose ${ }^{13}$. Em outras versões, também é mencionado que Deus é denominado otompa, que é também o nome original do sol, hoje chamado wechu. Dessa maneira, o herói cultural é uma aranha, um aspecto do sol; desceu à terra como um raio de sol em meio à neblina, na forma de um fio de seda ${ }^{14}$; e é hoje associado com o Deus cristáo. Quando chamado Amoricha, e ao agir na terra em sua forma humana, ele é considerado uma pessoa humana falecida (como indicado pelo sufixo -cha) que possui o conhecimento da construção.

O verbo transitivo empregado para indicar o processo de deixar o casulo é etoka, ${ }^{15}$ sair de algum lugar, sair de um abrigo ou invólucro, como um ovo, por exemplo, ou como quando uma garota sai da cabana de menstruação, neste caso o casulo. Outros verbos além de -etoka são empregados neste mito para transmitir o sentido de sair. Um deles é -eke, aparecer, sair, tornar-se visível, como o sol que nasce de manhá ou as plantas que saem do chão. Uma terceira maneira de expressar tais aparecimentos é articular a ação de aparecer por meio da imagem sonora chep, chep, chep. Enquanto etoka expressa a perspectiva e a ação daquele que está saindo de um invólucro, -eke se refere à perspectiva do observador, e chep é o símbolo sonoro que indica a ação de aparecer.

O casulo partido se torna a base de um universo com múltiplas camadas. Uma parte dele vem abaixo, enquanto a outra permanece acima e isto cria diferentes mundos, owaya. Tanto este mundo, o espaço entre o firmamento e o solo, nono, quanto o outro mundo sobre o céu, aqui também chamado owaya, passaram então a existir.

\section{Maneiras de alargar e de tecer o mundo}

Após haver alargado a terra originalmente pequena, o herói cultural começou a construir o mundo por meio de diferentes atividades. $\mathrm{O}$ verbo usado neste contexto de alargamento da terra é -aĉho-normalmente traduzido como transformar, mas seu sentido mais preciso é 
fazer com que algo esteja acontecendo. Naĉhopnako [n-aĉho-p(a)-nako; 3p-fazer acontecendo-Prog-pasH], ele estava fazendo algo acontecer no passado histórico. Em outras versóes, o verbo "crescer" é empregado para descrever este processo de fazer algo acontecer. Ele fazia a terra crescer.

Ao alargar o solo nono ele, entretanto, não estava automaticamente erguendo-se e alargando owaya, o espaço entre o firmamento e a terra. De acordo com algumas versóes irapa e sokorpa, a ampliação desse espaço se tornou necessária na medida em que estava fazendo tanto calor na terra que a água nos rios e lagos estava fervendo. O firmamento estava próximo à terra e havia entáo dois sóis no céu, de forma que nunca escurecia. Amoricha estava atirando (-ama-) flechas com pontas cegas feitas de cera de abelha preta em direção ao sol, e então o firmamento começou a subir. E ele atirou no olho de um dos sóis, que ficou preto e se tornou a lua ${ }^{16}$. Assim ele estabeleceu a distância necessária e criou as diferenças entre o dia e a noite, o calor e o frio, o seco e o molhado e deste modo criou, na terra, as condiçóes propícias à vida. Atirar com arco e flecha é neste caso uma atividade que não tem a intenção de matar. Não é uma atividade predatória. Muito mais que isso, trata-se de uma atividade que estabelece contato, que transforma o outro e cria a distância necessária para as condições propícias à vida. Amoricha está alargando o mundo owaya, o espaço entre a terra nono e o firmamento, no qual se vive.

De acordo com as versóes Iroka, o herói cultural estava tecendo (-tkape-) as montanhas, as árvores e as folhas de modo a prover sombra, formando dessa maneira os contornos próprios do mundo. O Deus-pai então estabeleceu a vida como a conhecemos hoje e criou as condiçóes para ela, que se baseiam na alternação balanceada de diferenças, na formação dos contornos do mundo e na criação das formas de vida.

Então caiu em sua própria memória [otoway nantanako] de Deus-pai [pensamento de Deus-pai]: "Não, estou sozinho aqui". Imediatamente [ele perguntou] "Quem será como um companheiro para mim?"17

Primeiro, as pedras foram como suas companheiras. Ele teceu pedras para si mesmo. Uma grande pedra para si mesmo, ele estava tecendo, e também uma outra, duas pedras. E depois disso o Deus-pai pensou: "Não, mas isto não é como um companheiro". [Ele estava] incomodado com seu companheiro-pedra. "O que é isso, será possível que elas não vão se reproduzir [epameĉhaĉh], essas pedras? Não, elas não são como companheiros. Não, como é possível que elas sejam como minhas companheiras?” Disse o Deus-pai. ${ }^{18}$ 
Naquele tempo ele já havia feito tudo, as árvores e montanhas e estava andando pela floresta. Então ele encontrou primeiro uma (proto-)anta fêmea, e a desposou.

Primeiro ele encontrou a anta, e com a anta ele se juntou. "Quem é você? Por que você tem um traseiro tão grande?” ele disse. Ela era como uma mulher. Então ele foi e seu juntou a ela, o Deus-pai. Com essa anta ele se juntou. Ele disse: "Você é uma esposa linda". "Eu gosto muito de você", a Anta disse para o Deus-pai. "Você será uma boa esposa para mim", ele disse. "Eu não tenho filhos", ele disse, "com você eu vou me reproduzir". Ele a levou consigo. Com suas palavras [ywonkzse] ele fez uma casa parecida com as casas dos brancos, para que pudessem viver lá. Ele costumava tecer uma casa com suas palavras. Dessa forma, [ele] costumava tecer a casa. Ele trouxe a anta junto com ele, como sua esposa, como sua esposa. Os dois estavam dormindo juntos. Depois de um tempo, ele estava pensando. O Deus-pai disse "Não, você não está se reproduzindo. Por quê? Você é uma mulher estéril? Você é estéril. Uma mulher estéril você é. Você ficará sem filhos" ele disse e pensou: "Saia, vá para a floresta, seu nome será achache (anta)" 19 .

Após o herói cultural ter transformado a anta, ele encontrou com wayé, o bicho-preguiça:

Depois disso ele estava pensando novamente, e, no caminho, cruzou com a preguiça. A preguiça ele encontrou, a preguiça. Ele disse "Você é uma mulher". "Com você vou me reproduzir [epams ya]", ele disse para a preguiça. "Como [para quê] é esta mulher?". "Você será minha companhia feminina, minha esposa", ele disse para a preguiça. Ele estava dizendo isto a ela. Então ele levou ela junto com ele para onde o lugar onde a anta havia sido sua mulher [onde ele havia vivido com a anta]. Ele fez uma casa com as palavras que disse, uma casa como a do homem branco. Lá estava a casa. Neste tempo era assim, assim. Depois disso ele deu animais jovens [ynépĉh] para ela. Alguns jovens [ynépçh], assim. (...) Eles eram assim, ele os deu a ela. O pequenino, que ele havia tecido, ele o deu para ela. "Leve as crianças. Você vai fazer eles crescerem como crianças". O Deus-pai estava dizendo para a preguiça. Ele já estava dando as crianças-animais [ynéch hpe] como se fossem pequenas crianças humanas [machukapash]. Ela estava crescendo eles [criando e cuidando deles] [satznkapo]. E mais uma vez ele deu mais para ela, nossas pequenas crianças [machukapash] ele estava tecendo e já estava dando. Novamente ele deu crianças para ela [machukapash]. Mais uma vez ele havia tecido e estava dando-as a ela, colocando-[as] em sua mão. Mais uma vez ele deu a ela, mais uma vez. Entáo ele deu a elas duas mãos cheias, dez [crianças] a ela ele deu, ele deu a ela. Depois disso ela os fez crescer, ela os fez crescer [e] eles começaram a voar. Eles eram os filhos de Deus. Ele pensou "Eles serão pássaros". Estes foram os seus primeiros filhos ${ }^{20}$.

O mito retrata uma sucessão de pares generificados que tentam se reproduzir, desde os parceiros menos parecidos com humanos - as pedras -, que acabaram não sendo companheiras, até a anta, uma companheira que no fim das contas não pôde dar à luz, e a 
preguiça, que estava criando os filhos de Deus, mas - como veremos - entrou em um relacionamento incestuoso. Os protoanimais são finalmente transformados em animais e enviados para viver na floresta. Estes "pares reprodutivos", unidades de dois que procriam, são as entidades econômicas e sociais básicas entre os Yukpa, e representam a forma normal e adequada de se viver. Estar e existir sozinho - como fazia o herói cultural - é, por contraste, um estado de existência incompleto. As unidades reprodutivas não podem - tal a mensagem deste e de outros mitos - ser formadas por indivíduos que são ou distantes demais, de modo que a reprodução se torna ou impossível ou monstruosa, ou próximos demais, o que seria incestuoso ${ }^{21}$.

\section{Tecendo, criando filhos e transformando animais}

A fabricação parece ser a forma geral para se fazer algo acontecer no mito. O herói cultural está tecendo o mundo, as montanhas, as árvores, as folhas, as pedras e até mesmo seus primeiros filhos. Tecer e construir, a exemplo do mito, não equivale a reproduzir ou multiplicar [-epame-]. Pode-se fabricar sozinho e mesmo por si próprio, mas não procriar. A reprodução requer um outro. De fato, a procriaçáo sexual e a reprodução permanecem impossíveis com os outros originais, os protoanimais. Os protoanimais míticos são, dessa maneira, e a despeito do fato de que partilham da linguagem e da cultura com os homens, apenas parecidos com os Yukpa, Yukpape mas não Yukpa.

A reprodução se torna possível com a preguiça, mas ainda assim não é a reprodução fisiológica baseada na procriação sexual. A reprodução está baseada na fabricação realizada por meio da tessitura e pela criaçáo e cuidado com as crianças em uma relação quaseadotiva $^{22}$. É esta relação de familiarização (Erikson, 1987 e Fausto, 1999) que os Yukpa empregam hoje para criar e cuidar dos filhotes de animais que foram caçados. $\mathrm{O}$ fato de dois termos distintos serem usados nos mitos para designar os filhos das mulheres é sugestivo. Deus está dando ynépch h, jovens animais para sua mulher, indicando por meio disto que as crianças que ele teceu são crias de animais, não crianças humanas. Entretanto, ela cuida deles como se eles fossem suas próprias crianças humanas pequenas, machukapash. Criar e cuidar de crianças, inclusive as adotadas, é expresso com o sentido de fazê-las crescer (ver abaixo). O termo empregado é atzn[a]-ka-po, uma forma personificada de fazer algo 
crescer progressivamente [atzna]. Se em um primeiro momento as crianças são criadas como se fossem crianças humanas, elas, contudo, começam a voar e se tornam diferentes espécies de aves de rapina epuko.

Processos vitais importantes são conceitualizados como formas de fabricação. Enquanto animais e crianças podem ser feitos e manufaturados, artefatos podem ser feitos crescer, como veremos. Porém, artefatos não são conceitualizados como seres vivos entre os Yukpa. As coisas que alguém tece ou fabrica geralmente pertencem à classe das coisas íntimas ou de propriedade pessoal. Elas são marcadas por um prefixo pronominal possessivo específico, que indica de quem essas coisas são (minhas, suas, dele) e não existem sem tal indicação de posse íntima. Esses substantivos possuídos incluem partes do corpo, parentes próximos, objetos manufaturados e os resultados de intervençôes físicas no meio ambiente, tais como uma roça aberta. É impossível dizer apenas "nariz", pois isto é sempre "meu nariz", "seu nariz" ou "o nariz dele" - ena, yena ou yona. De modo que a terceira pessoa do singular yona é empregada quando se está simplesmente falando de "um nariz". Além das partes do corpo, o local onde alguém dorme, sua casa, sua bolsa, seu cachimbo, colchão, roupas, armas e roças são substantivos possuídos íntimos sobre os quais esta pessoa tem uma maestria estendida, que os outros devem respeitar. Não se deve entrar sem permissão, pegar coisas ou mesmo tocá-las. Elas são extensões da pessoa e compartilham seu espírito. É por isso que, após a morte de uma pessoa, elas devem ser destruídas ou então não podem ser usadas, como no caso das roças. Nesse sentido as montanhas, florestas, árvores e aves de rapina originalmente fabricados pelo herói cultural são extensóes possuídas da sua pessoa e não o resultado da reprodução, que implicaria a participação de outros. E, como a reprodução adequada não é possível com esses outros originais, eles estão banidos.

O herói cultural envia suas mulheres e filhos para a floresta e, ao fazê-lo, os transforma nos animais contemporâneos. Esta é o movimento alternante e de distanciamento por meio do qual extensões de si tornam-se outros. Um conflito, como veremos abaixo, ou a impossibilidade de se reproduzir levam à separação. No mito, tais separaçóes são acompanhadas de um procedimento padronizado, incluindo a atribuição de nomes, a definição de um local de habitação, a indicação do que os animais hão de comer e, com isto, a relação que eles estabelecerão com outros seres. Neste processo, protoanimais formalmente parecidos com homens são transformados em animais de verdade, esposas incompletas se transformam em presas. 
Como demonstra um mito irapa, o "conhecimento para transformar" [tzwantashatzwan-ta-sha conhecimento - é (para fazer) - isto é para aquilo] não está apenas baseado na atribuição de nomes, hábitos alimentares e locais de vida, mas na fabricação de atributos corporais, como ao afiar as unhas, garras e dentes e ao distribuí-las a diferentes espécies enquanto cantam-se músicas poderosas [irimi], que são conhecidas como alemi na Guiana $^{23}$. Por exemplo, Deus está distribuindo e implantando diferentes formas de dente nas cobras, pica-paus e humanos, cujos dentes são feitos de milho. Mas, no todo, a diferenciação das espécies vai além de um processo de fabricação de diferenças corporais, pois implica a definição de diferentes hábitos alimentares, relaçóes com outros seres e nichos ecológicos, e está baseada em fazer a transformação acontecer por meio de cançôes. Protoanimais eram como os Yukpa, Yukpape, parecidos com eles, mas não eram Yukpa. De fato, sua diferença torna-se visível na medida em que a procriação permanece impossível $\mathrm{ou}$ - como veremos - em que eles violam o tabu do incesto. Eles se tornam animais porque não são plenamente humanos.

Fazer acontecer [-acho-], o conhecimento de transformar [tzwantasha] e de fazer crescer $[$ atznka] (ver abaixo) são atividades que não necessariamente se referem apenas a intervenções físicas e atividades instrumentais de fabricação. Fazer algo acontecer não é apenas uma manipulação técnica de materiais, mas pode ser feito por meio de palavras (wonkz), feitiços (pshkech), cançôes (yochhéme [iro] yorimi [ira]) ou pensamentos. Foi pensando que ele fez a terra crescer. Os feitos pshkech são mencionados em várias ocasióes no mito iroka. Pshkech, o herói cultural queria ficar bêbado, e lá estava a cerveja... pshkech ele queria ser servido, e eles trouxeram a ele uma cabaça para beber... pshkech ele queria que esses animais saíssem de lá e vivessem muito longe na floresta... pshkech ele os enviou para as árvores altas. Assim ele fez com que as coisas acontecessem. O que há de comum nessas ações instrumentais, comunicativas e cognitivas é que elas estão simultaneamente (re)organizando e (re)estruturando relações físicas, sociais e cognitivas entre materiais, seres e pensamentos.

Por fim, o herói cultural também está rejeitando e transformando o irmão da preguiça, o pica-pau de topete vermelho, sakúchhas, e suas próprias crianças, as aves de rapina, epuko. A razão para isso não é, neste caso, a impossibilidade da reprodução. Como vimos, uma certa - ainda que incompleta - forma de reprodução ocorre com a esposa preguiça. A razão é assim muito mais uma forma errada de reprodução. A transformação 
dos protoanimais em animais é explicitamente relacionada nos mitos irapa ao fato de que os animais estavam violando o tabu do incesto durante um banquete em que eles estavam bêbados. A versão iroka afirma que a esposa preguiça de Deus, seus filhos e o irmão da preguiça não se comportaram adequadamente durante uma bebedeira de chicha. Eles estavam oferecendo ao herói cultural cerveja de milho em uma cabaça suja e deram a ele uma esteira velha e suja para se sentar. A preguiça estava cantando, dançando e curtindo com seu irmão mais novo, sem se importar com seu marido. Então Deus ficou com raiva, deformou os pés da preguiça e do pica-pau, transformou a ambos em animais e os mandou para a floresta. É por isso que a preguiça e o pica-pau têm pés deformados - tanto que dificilmente conseguem andar no solo plano. O herói cultural disse então que a preguiça irá se nutrir de brotos e plantas jovens macias, e o pica-pau se alimentará de minhocas [kwchhasha]. Os seres vivos são, portanto, definidos por suas formas específicas, sua maneira de reprodução e por suas relaçóes com outros seres.

\section{Maneiras de crescer}

Nas linhas introdutórias do mito, o verbo para crescer -atá- é mencionado. O sol-aranha estava crescendo $n$-atá-nak $[3 \mathrm{p}-$ crescer - pasH] no passado histórico. Este verbo, -atárefere-se ao crescimento das plantas, cabelos e dentes, que crescem por si próprios no sentido de que saem de dentro ou brotam. O Deus-Sol estava em seu casulo crescendo como uma planta. Por contraste, quando ele desceu e transformou - achbo- a terra, se diz que ele fez a terra crescer -atzna-. Tanto -atzna- quanto -atá- são verbos intransitivos, o que indica que o processo de crescimento é conceitualizado tanto gramaticalmente, como também na vida comum yukpa, como algo que está acontecendo por si próprio, sem a intervenção de qualquer pessoa.

O que é significativo aqui é a diferença entre as duas formas de crescer, -atá- e atzna-. Enquanto -atá- é, como indicado, usado para o crescimento de plantas, cabelo, dentes ou unhas, -atzna-, por contraste, refere-se ao crescimento de seres personificados que são considerados como tendo sangue, como os animais e os humanos. Enquanto o solaranha estava crescendo como uma planta, a terra está crescendo como um ser personalizado, possuindo sangue como animais e humanos. Não é por acaso que os Yukpa 
contam estórias sobre non-piri, o pênis da terra que penetra e engravida as mulheres yukpa, e que ninguém deve sentar no chão sem usar uma esteira ou um pedaço de madeira. Antes de plantar milho [me], deve-se tornar o solo adocicado por meio do plantio de outros frutos como batata [shá], mandioca doce [pó], abóbora [kuwé] ou feijão [kumáta]. Entre os Yukpa não apenas o solo, mas até mesmo as pedras podem escutar, atacar, ir de encontro a alguém ou cercá-lo. As pedras, mesmo que não sejam uma companhia adequada e que não sirvam para procriar, são referidas como sendo mansas [kowaso] ou selvagens [esó] e são dotadas de agência. $\mathrm{O}$ mesmo é verdadeiro para as estrelas.

Enquanto essas duas formas de crescimento são conceitualizadas como algo que está acontecendo por si só, uma delas pode se tornar um verbo transitivo por meio do marcador de transitividade $-k a$. Dessa forma, crescer torna-se uma atividade iniciada por uma intervenção externa, "alguém está fazendo isto crescer”. Assim, formas personificadas [-atzna-] e impessoais [-atá-] de crescer podem ocorrer por si mesmas, mas apenas [-atzna-] pode ser iniciado por alguém. A forma impessoal do verbo crescer -atá- poderia, teoricamente, ser transformada em um verbo transitivo, mas isto praticamente nunca ocorre. Atá permanece como o crescimento impessoal que acontece por si só. Apenas seres personificados ou coisas que são posses íntimas podem ser feitos crescer.

Fazer algo crescer é, assim, ao mesmo tempo uma capacidade, uma forma de poder ou uma maestria que está sendo exercida por alguém. Dessa forma, crescer não é mais um processo quase biológico e autorreferencial que acontece por si mesmo, mas se torna uma forma de fazer. Enquanto o crescimento do sol-aranha está acontecendo por si próprio, a terra é feita crescer pelo Deus. Nem todo crescimento é, assim, fabricação e não depende necessariamente da ação humana ou de uma ação externa, do mesmo modo que a habilidade manual não provê o modelo para todos os atos criativos. Não apenas a maior parte das plantas ${ }^{24}$, mas as larvas e os casulos (como o herói cultural durante seu estado de metamorfose) e também garotas durante a reclusão menstrual estão crescendo por si mesmos. Diferentemente, as crianças são, como veremos, feitas crescer quando alimentadas e cuidadas.

Assim, enquanto nem todo crescimento é fabricação ou fazer crescer, a fabricação, por sua vez, pode ser uma forma de crescimento. Artefatos como cestas, esteiras ou bolsas crescem progressivamente durante o processo de confecção, atzpepo. Crescer pode, portanto, ser uma auto- ou exo-atividade, realizada sobre ou por alguma coisa. O último 
pode ser praticado por aqueles que têm o poder de exercer influência sobre outros. Esses uatpe que exercem a maestria podem ser humanos ou donos de plantas e animais ${ }^{25}$. Além disso, ao fazer algo crescer, uma pessoa pode tornar-se seu uatpe. E, por último, mas não menos importante, o crescimento como uma exo-atividade de fazer algo crescer [-atztnka-] ou de fazer com que algo esteja acontecendo [-aĉho-] se apoia não apenas em uma série de manipulaçóes instrumentais da matéria (tecer e alimentar, por exemplo), mas também em atividades não-instrumentais (como cantar ou proferir feitiços). Esses processos estão baseados na reestruturação simultânea de relaçóes cognitivas, sociais e materiais.

\section{Fabricando os Yukpa que crescem como plantas}

Quando o herói cultural transformou sua esposa, a preguiça, o irmão dela, o pica-pau, e suas crianças, as aves de rapina, em animais e os enviou para a floresta, ele ficou sozinho novamente.

Não havia ancestrais. Havia o pica-pau. Deus estava sozinho em sua casa. Ele estava só. O pica-pau havia se retirado para longe de onde o Deus-pai estava. Mas ele estava se aproximando de Deus novamente. Ele veio para perto, e estava cantando, wek wek.

"Huy, por que você voltou?" [Deus perguntou]

O pica-pau disse "Não, papa, eu encontrei uma árvore grande no cerrado e, quando eu estava batendo nela com meu bico, ela começou a chorar e a sangrar". dizendo]?”

"Onde ela está? No cerrado? É verdade isso [o que você está

"Sim, é verdade, lá está ela" [disse o pica-pau]

O herói cultural finalmente foi convencido e aceitou ir até lá, levando seu machado consigo. Pica-pau então levou o herói cultural em uma longa viagem, com muitos desvios, ao longo da rota mais difícil que passa por dentro da floresta, porque ele queria se vingar de Deus por sua expulsão. Finalmente, após muitos dias, ele mostrou ao Deus a árvore que, na realidade, ficava bem perto do lugar onde Deus vivia. Assim que eles chegaram o pica-pau disse ao Deus para cortar - $u k a$ - toras da árvore e para leva-los a sua cabana.

Nesta árvore chamada manztchacha ou caricai, no espanhol local, estavam vivendo os Yukpa. O sufixo - cha indica que essa árvore já foi humana uma vez, em contraste com o 
sufixo que é comumente usado para árvores -yi. Ela tem uma resina líquida de cor vermelha, que pinga como sangue se for feito nela um corte de facão. Enquanto o pica-pau de topete vermelho estava bicando a árvore à procura de alimento, ela começou a sangrar e é por isso que hoje ele tem sua penugem vermelha cor de sangue. Ainda hoje os Yukpa estão convencidos de que eles foram feitos desta árvore. Como um Yukpa uma vez me disse, "ainda há Yukpa ali dentro".

Em algumas versóes irapa, duas mulheres emergiram das toras. Amoricha as desposou, e procriou com elas. Nas versóes iroka e sokorpa, tanto homens quanto mulheres são feitos da árvore e começam a procriar entre si. Hoje, diz-se que não apenas os Yukpa mas também os wateya, os brancos, emergem daquela árvore. Em versóes de mitos mais antigas, os brancos não emergiram da árvore manłtchacha, mas eram considerados como seres monstruosos que resultaram tanto de relaçóes sexuais incestuosas como também da masturbação (Wilbert, 1974: 92f) ou foram feitos de uma madeira distinta, chamada kiriyi $i^{26}$.

Nas versôes irapa e sokorpa, após ter cortado as toras e as colocado em sua casa, o herói cultural partiu na manhã seguinte para trabalhar na floresta. Quando voltou ao fim da tarde, a comida estava cozida. Ele se perguntou quem poderia ter feito isto. As toras ainda estavam na cabana. No dia seguinte, o mesmo aconteceu. No terceiro dia ele observou sua casa à distância, e viu duas mulheres saindo das toras e fazendo o trabalho. O pica-pau disse para ele ir lá agarrá-las [-puchu-, pegar, tomar com as mãos] e fazer cócegas nelas (sutankarapma, fazer cosquinha nas costelas) para fazê-las rir. E foi isso que ele fez. Assim que elas começaram a rir, elas não mais se transformaram e permaneceram humanas. Como uma medida adicional, na versão sokorpa o herói cultural destrói seu abrigo, o invólucro de madeira do qual elas emergiram antes do Deus ter feito elas rirem. Dessa forma, elas não tiveram mais chances de retornar. A mesma palavra para invólucro (yushru [sok], yuschu [iro]) é usada para as toras de madeira e o casulo do Deus-aranha.

Na versão iroka o herói cultural diz:

Elas dormiam ali na árvore cortada, mas elas já haviam deixado suas pegadas [quando elas estavam cozinhando]. [Então o Deus-pai sabia]. "Fique de pé [twanse] como nós” [ele disse]. Com essas palavras ele fez crianças. Quando elas estavam se levantando e ele olhou para elas, ficou contente. "Huy, quem são vocês? Vocês são os meus filhos. Para sempre vocês vão se reproduzir [epamse]. Vocês se parecerão comigo. Vocês vão sempre 
se reproduzir. Vocês vão ficar crescendo [matánato]. Os Yukpa e os brancos [já que ambos saíram da árvore] serão sempre como $\mathrm{eu}^{27}$.

Quando os Yukpa deixaram a árvore, eles ainda estavam rígidos como a madeira. Então ele começou a quebrá-los, e fez as articulaçôes para que eles pudessem se mover e trabalhar melhor. Quando eles estavam terminados, todos os animais já tinham tido filhos, mas não os Yukpa. Finalmente, eles aprenderam dos pássaros como se reproduzir sexualmente:

“'Bom, você quer saber como fazer aquilo?', os pássaros disseram. 'Traga a sua mulher [para aprender] como abraçar mulher para ter filhos"”.

Eles mostraram aos Yukpa a técnica de como se deve enlaçar a mulher para ter filhos. E os pássaros os deram suas crianças para criar. "Ah! Então é assim que é uma criança”, os Yukpa disseram. E finalmente os pássaros explicaram como eles devem inserir $\left[\right.$ tpatach $\left.^{28}\right]$ seu pênis bem fundo para ter filhos.

Então os primeiros Yukpa, contrastando com os protoanimais, não foram expulsos da floresta. Eles foram trazidos da floresta para a casa do Deus-pai. Eles já existiam dentro da árvore manuchacha e foram descobertos pelo pica-pau. Esculpidos em toras de madeira, eles saem de seus invólucros e se transformam em seres humanos. Eles crescem da árvore e quase automaticamente assumem tarefas femininas ou generificadas, como o fazem os brancos e os Yukpa, que têm diferentes habilidades e capacidades desde o início. Mais tarde, o Deus faz para eles articulaçóes. Como os Yukpa já estão evidentemente vivendo como seres completamente desenvolvidos dentro da árvore, Deus não os fabrica, mas meramente os refina, adicionando articulaçóes no processo descontínuo de uma "sequência operacional" (chaîne opératoire) (ver Pitrou, 2014; Lemonnier, 2012 e Coupaye, 2013). E, finalmente, em uma situação na qual todos os animais já sabiam como procriar sexualmente, eles aprendem mimeticamente as habilidades da reprodução sexual dos pássaros.

Noções relacionais e transformacionais da vida: da morada espacializada à metamorfose

Então, o que é que está contido no quadro simbólico comum de fabricação entre os Yukpa? Como mencionado acima, artefatos manufaturados náo são nem pessoas nem se 
transformam em partes do corpo $^{29}$, tampouco têm o poder de transformar-se em outras coisas. Mesmo que os Yukpa tenham emergido de uma árvore, não é a transformaçáo das coisas em sujeitos que compóe o foco do quadro simbólico comum de fabricaçáo. Mais que isso, é sobretudo a transformação, concebida na forma da liberação de seres já existentes de um invólucro, e seu adicional refinamento técnico que ocupam a posição central.

Os processos vitais conceitualizados e verbalizados neste mito abrangem formas bastante diversas de fabricação, várias noções de crescimento e formas de reprodução, sexuais ou não. Esses processos podem ser distinguidos entre aqueles que se baseiam tanto em fazer com que algo esteja acontecendo [-achoachho-], quanto no crescimento autônomo ou na reprodução sexual. A primeira categoria (fazer com que algo esteja acontecendo) é certamente a mais complexa das três, na medida em que contém diferentes formas de como produzir as condiçóes e formas de vida por meio das palavras, pensamentos, habilidades técnicas e pela mudança de relaçóes (tecendo, cortando, atirando, pensando, cantando). Nem todas essas atividades se baseiam apenas nas habilidades manuais. Elas implicam habilidades comunicativas e cognitivas, assim como sequências operacionais e a cooperação entre gêneros, no caso da reproduçáo adotiva náo-sexual. E, por último, mas não menos importante, fazer com que algo esteja acontecendo inclui o conceito de -atznka- a confecção do crescimento personificado.

O crescimento autônomo, por si próprio, em contraste, ocorre tanto em formas impessoais [-atá-], quanto pessoais [-attzna-], enquanto apenas este último pode se tornar uma forma de fazer crescer [-atztnka-]. A reprodução sexual [-epame-] é claramente diferenciada da fabricação e das maneiras com que se faz algo acontecer, assim como do crescimento, sendo baseada em pares generificados que não são nem muitos distantes, tampouco muito próximos.

Os aspectos do mundo fabricados ou transformados por esses processos podem ser localizados em diferentes níveis. Em um nível macro está o universo dotado de múltiplas camadas e este mundo, que foram ambos alargados e tornados habitáveis como um resultado do crescimento, do atirar com arco e flecha, e da ascensão do firmamento e diferenciação entre sol e lua, dia e noite e seus ciclos alternantes equilibrados. Em um nível intermediário, nesta terra, pedras, montanhas e árvores foram tecidas, assim como foram, em um nível micro, a casa e alguns animais, que são os filhos do herói cultural. 
Entretanto, nenhum dos elementos que foram feitos crescer, tecidos ou transformados se tornam um Yukpa; a reproduçáo permanece adotiva e náo-sexual. Os animais prototípicos, como a anta ou a preguiça, acabam por não ser plenamente humanos, na medida em que a procriação permanece impossível ou se torna incestuosa. Os protoanimais são, como uma consequência disto, transformados em animais contemporâneos, com suas formas de vida particulares e suas relaçóes com outros seres em lugares específicos da floresta que lhes foram designados pelo herói cultural.

Assim, o quadro simbólico de fabricação partilhado (Santos-Granero, 2009) é, a um primeiro olhar, definido pelas atividades de construção e feitura do herói cultural. Claramente, a habilidade manual precede a gestação. Contudo, a habilidade manual realmente provê o modelo para todos os atos criativos? São realmente todas as diferenças entre organismo e artefato apagadas, todos os processos biológicos fabricados? O sol-aranha está tecendo, preenchendo, esculpindo e cortando, mas há crescimento [-ata-] que não se apoia na fabricação; além disso, o sentido de fabricação ultrapassa as noçôes comuns da habilidade e artifício manuais. O herói cultural não apenas está realizando habilidades técnicas e manuais, mas está tecendo com suas palavras e pensamentos, transformando com canções e fazendo coisas acontecerem por meio de feitiços. Obviamente, o fabricar está baseado na realização de pensamentos, intensões e desejos, e implica processos de feitura materiais, cognitivos e sociais. O herói cultural possui o poder de fazer as coisas acontecerem por meio de processos que abrangem habilidades interativas e instrumentais. Fazer as coisas acontecerem em um mundo no qual as relaçóes com seres não-humanos e vários aspectos personalizados do mundo são relaçóes sociais, dificilmente pode ser um processo restrito a atividades instrumentais. Isto implica o conhecimento e o poder para fazer as coisas acontecerem por meio de pensamentos e da comunicaçáo (cantar e proferir palavras), e implica a transformação de relações sociais. O Deus-pai assegura a distância necessária ao atirar com seu arco e flecha, transformando os protoanimais que se pareciam com os Yukpa em animais com diferentes habitats e hábitos alimentares, e estabelecendo relaçóes íntimas ao tomar as mulheres e infundir-lhes sentimentos humanos por meio das cócegas, que as fizeram rir. A fabricação, portanto, ultrapassa as habilidades técnicas e a formação de diferenças corporais, implica tecer ideias e pensamentos por meio de intervenções espirituais, atividades interativas, tanto comunicativas quanto técnicas e instrumentais. As últimas estão embutidas nas primeiras e são parte delas. Fabricar neste 
sentido amplo estende-se para além da habilidade manual e está intimamente relacionado com fazer algo acontecer, assim como com fazer algo crescer.

Além da ampla área da fabricação na forma de fazer algo acontecer e fazer algo crescer, há uma área de crescimento autônomo. Os Yukpa reconhecem formas de crescimento impessoais e autopoiéticas, quase biológicas, que se situam para além do campo amplo da fabricação. De fato, não apenas muitas plantas, dentes etc. crescem por si mesmos. Os dois personagens principais - o herói cultural e os Yukpa - crescem como plantas [-atá-] e, no caso dos Yukpa, crescem de plantas. Ambos, sol-aranha e os Yukpa, já existiam em outra forma antes de terem finalmente deixado seus invólucros, sua capa de pele $y u s c \hat{c}$ t e terem se colocado em posição ereta.

Sair de um invólucro -etoka-, uma casca de ovo ou uma casca qualquer é uma indicação de haver nascido, de aparecer e de sair e se tornar visível -eke-neste mundo. Ser percebido como aparecendo e se erguendo, colocar-se na posição ereta e se levantar é um sinal de que alguém está vivendo. Como mencionado acima, enquanto -etoka- expressa a perspectiva e a ação daquele que está saindo de seu invólucro, de um lugar ou estado para outro, -eke- implica uma relação e refere-se à perspectiva do observador.

Esses processos vitais (nascer, crescer, fabricar e se reproduzir) também implicam processos de degeneração, e finalmente de regeneração e transformação na forma de processos vitais específicos. Se o antigo invólucro de alguém, seu yusĉhtz, a carcaça ou a madeira morre, não está mais vivo, oshepa, esta pessoa morreu ou expirou e saiu dele. Ao mesmo tempo, alguém nasce, se torna visível lá fora ou em outro lugar ${ }^{30}$. As noções de nascer, viver e morrer entre os Yukpa parecem dessa maneira ser fortemente espacializadas e posicionais, e correspondem apenas parcialmente com o início e o fim da reprodução biológica de um único organismo individual. Seu sentido espacializado é também relacional: alguém deixa um invólucro, aparece e posteriormente desaparece para alguém ou em relação a algum lugar. Viver, osesapa, significa estar vivendo ou residindo em algum lugar. A vida neste sentido é uma atividade relacional continuamente localizada. Deixar tal atividade relacional localizada é uma forma de morrer, aparecer é uma forma de vir à luz ou nascer.

A noção de vida carrega, ao lado de sua natureza espacializada, um sentido transformacional e transposicional. Em seu sentido transformacional, morrer em [sair de] um lugar significa nascer [aparecer] em outro. Alguém deixa seu invólucro, mas continua em outra forma ou em outro lugar. Os Yukpa são separados em um ciclo transformacional 
e reprodutivo que eles mesmos iniciaram. Após a morte eles vão à terra de seus ancestrais, mas não se transformarão em caça ou outros animais (ver Halbmayer, 2013a). Eles permanecem Yukpa na medida em que se comportam corretamente, mesmo que eles mudem sua forma depois de morrer e forem deste mundo para o mundo dos mortos. Ainda assim, o perigo é concebido de tal forma que, ao se comportar de forma incorreta, como ao cometer um incesto, uma transformação em animal pode ocorrer e as condiçóes hostis à vida do owaya tamoiya podem reaparecer.

A metamorfose, período transicional evocado pela figura do casulo, é associada à habilidade de sair ou mudar a própria pele durante os tempos de transformação após a morte, ou quando alguém se torna atzne, uma pessoa madura em reclusão. Como os mitos irapa exemplificam, enquanto alguns seres, tais como as cobras (kiripo, especialmente dentre elas yatama e owataku), escorpiōes (wasapu), grilos (kzrashu) e baratas (kishirap), vivem para sempre porque possuem a habilidade de trocar de pele e rejuvenescer, os Yukpa, que são desprovidos da habilidade de mudar sua própria pele, morrem ou vão embora para sempre e rejuvenescem na terra dos mortos (Halbmayer, 2013a). Mudar a pele e continuar a viver na mesma forma e no mesmo lugar como fazem as cobras ou escorpiôes implica, portanto, a vida eterna. Quando essa continuidade não pode ser assegurada, a reprodução sexual se torna necessária. A metamorfose, isto é, a mudança de forma e de lugar, implica somente em uma forma espacializada e relacional o nascimento e a morte, o início e o fim da vida. Observada do ponto de vista daquele que passa por uma metamorfose, há, contudo, uma continuidade da existência através de diferentes formas de aparecimento e de diferentes mundos ou lugares em que se habita. É por isso que há formas elaboradas de vida mesmo após a morte física. A vida neste sentido metamórfico não tem começo ou fim absolutos, nem para as pessoas individuais nem para o mundo. Mas há, como demonstrei, transformaçôes radicais e significativas, além de mudanças nas condiçôes e formas de vida que fazem com que a vida como as conhecemos hoje seja possível.

Se a vida vai além da vida de um organismo, e a vida de um organismo é parte de um ciclo maior de transformação e metamorfose, então normalmente apenas partes dessas transformaçóes podem ser observadas. Mesmo se nem sempre ou apenas parcialmente observáveis, morrer e nascer estão embutidos em uma lógica metamórfica como esta entre os Yukpa. Portanto, o início e o final da vida tornam-se pouco claros, na medida em que a morte física, isto é, deixar para trás um invólucro ou o corpo, não é uma morte social ou 
espiritual. É por isso que a noção de vida pode parecer opaca e é verbalizada entre os Yukpa como aparecer e desaparecer, -eke-, aparecer, tornar-se visível, ou -eka-, morrer, expirar ou evanescer. Viver ou estar morto, portanto, não é uma condição essencial de um organismo, mas a visão parcial e relacional que está embutida em processos mais amplos de transformação e metamorfose. Minha análise do mito Yukpa corrobora, dessa forma, a suposição de que "nós temos que estudar a vida como uma qualidade posicional" (Praet, 2013: 93), entretanto, como mostra o exemplo, essa qualidade posicional pode não ser capturada por uma simples oposição binária entre a vida e a morte. Ela está associada com o entrar e sair de foco, expresso pelo início e fim de atividades relacionais contínuas e localizadas. É por isso que, quando alguém morre, os Yukpa simplesmente dizem, me, ele se foi, foi aproveitar a vida na terra dos mortos. Mas a vida em seu sentido metamórfico ultrapassa essa atividade relacional localizada e inclui diferentes formas de existência neste e em outros mundos coexistentes. O fim real e definitivo da vida, uma segunda e última morte virá se estas transformaçóes cíclicas e metamórficas não mais ocorrerem ou chegam a um fim. O Deus-aranha náo teria que ter erigido a si mesmo neste mundo, e os Yukpa mortos que deixaram seus corpos nesse mundo não poderiam aproveitar a vida na terra dos mortos. Essa noção de vida ultrapassa a reprodução autopoiética dos organismos físicos e é dependente de uma recriação dupla: a recriação de atividades contínuas e localizadas em face à morte por meio da reprodução sexual e a recriação de transformaçôes metamórficas contínuas através de mundos e formas de vida distintos. Tais objetivaçóes da vida, conceitualizadas e verbalizadas nos mitos, além de relevantes para a práxis social, ultrapassam uma experiência vivida pré-conceitual, generalizada e teoricamente condensada em conceitos fenomenológicos como as "linhas-da-vida" ou "emaranhados" 31.

Tradução de Henrique Pougy e Erick N. Vidal

\section{Notas}

1 Uma primeira versão deste texto foi apresentada no seminário internacional "Des êtres vivants et des artefacts. L'imbrication des processus vitaux et des processus techiniques: Mésoamérique \& Basses-Terres d'Amérique du Sud" no Collège de France, em Paris, organizada por Perig Pitrou e Laura Rival. 
2 Growth, no original. Em sua forma verbal, to grow, este conceito abarca tanto os sentidos de aumento de tamanho e amadurecimento, como no português crescer, quanto os sentidos de germinação e cultivo de plantas. Também pode ser empregado no sentido de "criação", como aquele que "cria gado" (to grow livestock) ou cria/educa uma criança (to grow a child). Deste modo, o conceito cruza transversalmente as séries animal, vegetal e humana, distinguidas em português, adquirindo também uma conotação ativa e exógena (e não apenas passiva e endógena como em português): campo semântico que pode ser mais bem conotado por meio da expressão fazercrescer, pela qual optamos nesta tradução. [N.T.]

3 Interessantemente, nas abordagens ontológicas contemporâneas (Descola, 2005 e Viveiros de Castro, 1998), a análise dos mitos não tem destaque. Mitos, em vez disso, servem como uma linha de base generalizada usada para ressaltar a unidade original entre humanos e animais e o caráter altamente transformativo das concepções animistas do mundo. O olhar etnográfico do novo animismo e do perspectivismo dessa maneira raramente foca nos textos míticos, estruturas linguísticas ou as artes verbais presentes nos discursos indígenas. No centro da atenção está muito mais a percepção da prática relacional vivida entre os humanos e os não-humanos e não os discursos míticos e suas conceitualizações verbalizadas do mundo.

4 Para o debate sobre a história e o mito criticando a distinção de Claude Lévi-Strauss entre sociedades quentes e frias, ver Hill (1988), assim como a posição alternativa mais recente de Peter Gow (2001) que posiciona o foco na história do mito desenvolvida a partir da parte final das Mitológicas de Claude Lévi-Strauss. Para a incorporação de eventos históricos no mito ver também Guss (1981, 1989).

5 No sentido do termo original em Latim, o verbo concipere, tais conceitualizações não são necessariamente conceitos no sentido de um plano ou um design realizados sobre o mundo, mas formas de se conceber.

${ }^{6}$ Apesar de que em um artigo subsequente ele justapôs sua visão construcionista da existência contra uma visão perspectiva (Santos-Granero, 2012), ele também o fez sem especificar a noção de fabricação.

7 A definição clássica por Gregory Bateson: “informação é a diferença que faz diferença” (1972).

8 Esse processo se refere à construção de uma casa com estacas de madeira, diferentes pedaços de pau para as paredes e para a estrutura do telhado, assim como folhas de palmeira para a cobertura do telhado. $\mathrm{Na}$ medida em que as folhas de palmeira são tecidas neste processo, se pode referir ao processo de construir uma casa como "tecê-la".

${ }^{9}$ Como é por exemplo “Aquele que Faz a Vida” entre os Mixe (Pitrou, 2012, 2014).

10 A mãe do Deus, por exemplo, é mencionada na versão iroka. Não é claro se todos os protoanimais como a anta ou a preguiça que são mencionados nos mitos foram feitos pelo Deus ou se ele está apenas os transformando. Eu obtive diferentes respostas sobre este aspecto. Entretanto nunca foi afirmado que Deus fez seu duplo principal - e em vários quesitos dotado de maior conhecimento que ele - o pica-pau [carpinteiro em espanhol] sakúchbas [iro] ou sakúrare [ira].

${ }^{11}$ Esta versão foi narrada por José Manuel Garcia. Agradeço a Wilson Largo por seu suporte na tradução deste mito.

12 Papsh tyos twapa. Kantk ma papsh tyos monsenotk nako papsh tyos. ... kchokyotk ymemĉhepe newutnank. Kakoyo kach owaya. Ochtk oyotk nenutnak papsh tyos. Papsh tyos ysha achhaya kantk na yose achhaya. Tumempĉhushtk sha ynentunako. Nopotk papsh tyos monseno nako. Otaya papsh 
tyos monseno nako. Oĉhotk netókanako papsh tyos. Satk netokanak papsh tyos yusĉhtr. ĉhpat chont monseno nak yusĉht pa. Ywapay na takwna. Kamatk ntonak. Unkach nono kesh. Kakoyna owaya. Ostotk ntonak papsh tyos. Kantk natának papsh tyos. Nono ynatk ntktntanak. Oĉh tĉho yusĉhutk nonope na nutanako. Yon nukuntanako. Kas satk papsh tyos ntkanako. Wa kamsh naye nono nukanako. Ench yamach pa tumanka ntkanako. Shampetk ynaĉhponak shampe, naĉhopnak nono. Nono kam pskatk tłt nono shampetk nachopnak. Shampe, shampe saĉhopo.

13 Para a relação entre as larvas, a crisálida e as noções de viver, morrer, metamorfose e reprodução entre os Miraña e o complexo do Yurupari - ainda que contrastando com os Yukpa em uma versão parasita e predatória - ver Karadimas (2003, 2008 e este volume).

${ }^{14}$ Em outros mitos, o sol é figurado, por exemplo, caçando com uma teia de aranha formada por seus raios nos quais animais como veados são pegos.

${ }^{15}$ n-etoka-nako [3p - sair - PasH]: ele estava saindo no passado histórico.

16 O mito sokorpa é contado da perspectiva do deus-sol no céu. Ele está cansado de ser incomodado porque as pessoas atiram nele. Finalmente ele atira a si mesmo com a ponta de flecha de mapicha no olho. Os Sokorpa dizem que o sol era o olho de Deus.

${ }^{17}$ Kantk papsh tyos otoway nantanako. Wa awt chhko stye ya. Ench acho pakyope es naye.

18 Tó kasenopa tpakyope. Ytnkapenak tó. Tók sapnotk yünkape nak. Kosa tó tumanka ĉhpat. Kantk otoway nantanak papsh tyosh. Wa ma want pakyopepchash naye. $\mathrm{O}$ want tpakyope tó. Ĉhosh naye epameĉhach es naye tó chhosh wa want mash pakyope. Wa ench ota tus kach na pakyope es naye nttkanako papsh tyos.

${ }^{19}$ Kasenopa aĉhaĉhetk yun nosenpnako, aĉhaĉhe yun nosenpenak --eh otana tumoĉh naye mash tampe shampe nay yuwe nukanako. Tak woĉhepa oĉhan kash naye. Kantk ntonak yunatk nosepnak papsh tyos naaĉhaĉhe ytu nosepnak. Ntkanakkotk: amoĉh woĉhe patume naye ma. Ap koptne sha ntkanakotk aĉhaĉhe na pashp tyos. Amo kach kwĉhe ttawo es ma pa ntkanak. Wash naye awt wttshnt amo kachk na amoyatk na epams ya nttkanako. Kantk nanunako. Papsh tyos ywantktse tkak nak pen munttk yopo tweshnak tak wateya ywechpo. Oĉhatk munt skapep tweshnak twonkt kano. Oĉhko kankt skapep tweshnak munt. Oyetk naĉhunak aĉhaĉhe tutawnope, tutawnopw tumanka ĉhpat kantk oĉho nako nununako. Oĉho nak amenetka otayatkap tweshnako nukanako pash tyos: waa epameĉhash es ma. Otanop oĉhma amo woĉhe shaĉhtaneĉh oĉh ma amó shaĉhtane saĉhtanneĉh oĉh amo, entkachash es ma ntkanako. Nayanaktk. Enkap tok amupnaye. Amo ese aĉhaĉhek oĉh map nttkanako.

20 Wenaye chpat kantk otoway nantana tumanka chpat kantk wayé ypako nako, wayek ypako nak, waye. Nttkanakotk amo woĉhepansh oĉh ma amoĉh. Amo kach tk, amo ya kachpk epams ya nttkanako, nttkanakotk waye, ota nay oĉh woĉhepak oĉha, amo woĉhepa pakyope, otawnope, nttkanakotk waye. Kantk ytn nttkanak kantk naĉhunakotk. Pe ona chhpat chotp aĉhaĉhe ytnchanak munt ywontktka nako tak wateya ywechpo oyetk nako kantk oĉhotk nako. Pena pĉhk kantk ynech yuntunak. Sash ynépĉh [...] kas yun stupnako tkase kamshtk yun stupnako chumash wushnt. Amo wushnupe satuntka kantk yun kap nak papsh tyos waye na nukanako, penatk ynéĉhpe mashukapash y mashukapash skapepo pen esh nttt. Tumaka chhpat kankt ytn ytntunak mashukapash ytn ytuntunak, tumankak epo chhpat kantk tkasetk ytun stupnako kantk yomash sĉhtpnako. Tumanka epo chhpat kantk ytp stupnak, tumank, kantk yun ytntunak. Satka ytu ytntunako tak etopapne oma pkatka y 
nattnankotk, nattnankotk twãse tweshnako. Oĉh papsh tyos ywtshnt kantka oĉh otoway twanta tweshnak. Peshatk oĉhna kasenop ywtshntt.

${ }^{21} \mathrm{O}$ incesto implica o risco de uma transformação reversiva em owaya tamoiya, e em direção à animalidade (ver Halbmayer, 2004b)

${ }^{22}$ Sobre a proeminência e as formas de adoção entre os Yukpa, ver Halbmayer (2004c).

${ }^{23}$ Estas canções-feitiço são conhecidas na Guiana sob diferentes versões como alemi, ademi, aremi, eremu e eremi entre diversos grupos como os Wayana, Yerkuana, Waiwai, Waimiri-Atroari, Trio, Kariña, Pemon, os caribes do rio Barama, Akuriyo e os Apalai. Essas canções e cânticos são denominadas invocações, encantações e canções mágicas mas também com uma tradição com textos rígidos e exatos (Civrieux, 1980; 16) na literatura. Elas são meios de comunicação espiritual (Guss, 1986: 422 e Magaña, 1986: 43) que podem influenciar os espíritos (Civrieux, 1980: 16) ou servir como medidas curativas ou preventivas contra a doença (Arvelo-Jimenez, 1971: 209).

${ }^{24}$ Veja entretanto a nota 25 para as plantas que têm espíritos donos ou mestres e que são feitas crescer.

25 Algumas plantas que têm seus próprios espíritos mestres e são cultivadas, como o milho e a mandioca doce, são feitas crescer. O milho uatpe é até mesmo alimentado e nutrido ao se colocar colibris caçados no milharal. Mas há também algumas plantas selvagens importantes que têm seus próprios espíritos mestres, como as plantas curativas ou puk, a planta que é o material empregado para tecer cestas ou esteiras.

${ }^{26}$ As espécies de árvore kiriyi (guarumo, cecropia sp.) têm, em contraste com a árvore mantčhacha uma resina branca, cáustica e leitosa que se torna preta quando exposta ao ar. Muitos herbívoros evitam estas plantas, na medida em que a maior parte das Cecropia são myrmecophytes (plantasformiga), abrigando formigas Azteca em ramos ocos em uma relação simbiótica. Essas formigas defendem vigorosamente sua planta hospedeira contra as mordidas de outros animais e defendem a árvore especialmente contra as formigas saúvas (Atta sp.), kiavu, que são consideradas inimigos simbólicos dos Yukpa, sendo inclusive comidos por eles.

27 oy oĉhpat oĉh twentkatk saĉhp ytapnako, pena pĉhk kantk twansenak task ept ywontku ttt mashukash tweshnak twanse nak kantk key nensaĉhayna nyatemanakotk papsh ah, noĉh kach amóĉha, amóĉha, awt wushnt, amoĉha pĉhk epams manto nanape tak mena awt epaye pĉhk epams manto nanape amoĉh epams mant choĉh amoĉha pen matanato nttkanakotk wateya na ĉhpat oĉha ĉhpat tk nttkanako, amóĉha ĉhpat wateya pĉhk oĉh manto amoĉha nanape pĉhk awtt epaye es manto tak men yukpe pa nay... nanape pĉhk es manto, awt epaye ntkanakotk ytna.

${ }^{28}$ Enterrar ou enfiar, por exemplo, uma estaca em um buraco.

${ }^{29}$ Ainda que eles sejam extensões possuídas da pessoa que as fez.

${ }^{30}$ Sobre o tópico da morte e regeneração, ver Bloch e Parry (1982).

31 Ver Ingold (2011). 


\section{Referências bibliográficas}

ÅRHEM, Kaj

1996 "The Cosmic Food Web: Human-Nature Relatedness in the Northwest Amazon”. In Descola, P. e PÁlsson, G. (orgs.), Nature and Society. Anthropological Perspectives. Londres e Nova York, Routledge, pp. 185-204.

\section{ARVELO-JimÉNEZ, Nelly}

1971 Political Relations in a Tribal Society: A study of Ye'cuana Indians. Ithaca, tese, Cornell University.

BARANDIARÁN, Daniel de

1966 "El Habitado entre los Indios Yekuana”. Antropológica, Caracas, v. 16: 3-95.

\section{BATESON, Gregory}

1972 Steps toward an Ecology of Mind. San Francisco, Chandler.

BlOCH, Maurice e PARRY, Jonathan P. (orgs.)

1982 Death and the Regeneration of Life. Cambridge, Cambridge University Press.

BRABEC DE MORI, Bernd

2012 "About Magical Singing, Sonic Perspectives, Ambient Multinatures, and the Conscious Experience.” Indiana, Berlin, vol. 29: 73-101.

Civrieux, Marc de

1980 Watunna: An Orinoco Creation Cycle. San Francisco, North Point Press.

COUpaye, Ludovic 2013 Growing Artefacts, Displaying Relationships: Yams, Art and Technology amongst the Nyamikum Abelam of Papua New Guinea. Nova York, Berghahn. 
Descola, Philippe

2005 Par-delà nature et culture. Paris, Editions Gallimard.

ERIKSON, Philippe

1987 "De L'Apprivoisement a I'approvisionnement: Chasse, alliance et familiarisation en Amazonie Amerindienne”. Techniques \& Culture, Paris, v. 9: 105-140.

\section{FAUSTO, Carlos}

1999 "Of Enemies and Pets: Warfare and Shamanism in Amazonia". American Ethnologist, Malden/ MA, v. 26, n. 4: 933-956.

FORTIS, Paolo

2014 "Artefacts and Bodies among Kuna People from Panamá”. In Hallam, E. e InGOLD, T. (orgs.), Making and Growing: Anthropological Studies of Organisms and Artefacts. Farnham, Ashgate Publishing Ltd., pp. 89-106.

Gow, Peter

2001 An Amazonian Myth and its History. Oxford, Oxford University Press.

Guss, David M.

1981 "Historical Incorporation among the Makiritare: From Legend to Myth". Journal of Latin American Lore, Los Angeles, v. 7, n.1: 23-35.

1986 "Keeping it Oral: a Yekuana Ethnology". American Ethnologist, Malden/MA, v. 13, n. $3: 413-429$.

1989 To Weave and Sing: Art Symbol, and Narrative in the South American Rain Forest. Berkeley, Los Angeles, Londres, University of California Press. 
HABERLAND, Wolfgang

1957 "Black-on-Red Painted Ware and Associated Features in Intermediate Area". Ethnos, Stockholm, v. 22, n. 3-4: 148-161.

HALBMAYER, Ernst

2004a "Timescapes and the Meaning of Landscape: Examples from the Yukpa". In Halbmayer, E. e Mader, E. (orgs.), Kultur, Raum, Landschaft: Die Bedeutung des Raumes in Zeiten der Globalität. Frankfurt, Brandes \& Apsel, pp. 136-154.

2004b "Elementary Distinctions in World-Making among the Yukpa". Anthropos, St. Augustin, v. 99: 39-55.

2004c “'The One Who Feeds has the Rights': Adoption and the Relations of Kin, Affines and Enemies among the Yukpa and the Carib-speaking Indians”. In BOWIE, F. (org.), Cross-Cultural Approaches to Adoption. Londres, Routledge, pp. 145-164.

2010 Kosmos und Kommunikation: Weltkonzeptionen in der südamerikanischen Sprachfamilie der Cariben. Wien, Facultas Verlag.

2013a "Securing a Life for the Dead among the Yukpa. The Exhumation Ritual as a Temporary Synchronisation of Worlds". Journal de la Société des Américanistes, Paris, v. 99, n.1: 105-140.

2013b "Mission, Food, and Commensality among the Yukpa: Indigenous Creolization and Emerging Complexities in Indigenous Modernities”. Tipití: Journal of the Society for the Anthropology of Lowland South America, v. 11, n. 1: 65-86.

HALLAM, Elizabeth e INGOLD, Tim 2014 Making and Growing: Anthropological Studies of Organisms and Artefacts. Farnham, Ashgate Publishing Ltd. 
HiLl, Jonathan (org.)

1988 Rethinking History and Myth: Indigenous South American Perspectives on the Past. Urbana, Chicago, University of Illinois Press.

HoOpes, John W. e FONSECA, Oscar M.

2003 "Goldwork and Chibchan Identity: Endogenous Change and Diffuse Unity in the Isthmo-Colombian Area”. In QUILTER, J. e HoOpeS, J.W. (orgs.), Gold and Power in Ancient Costa Rica, Panama, and Colombia. Washington, D.C., Dumbarton Oaks Research Library and Collections, pp. 49-89.

INGOLD, Tim 2000 "Making Things, Growing Plants, Raising Animals and Bringing up Children". In Ingold, T. (org.), The Perception of the Environment. Londres, Nova York, Routledge, pp. 77-88.

2011 Being Alive. Essays on Movement, Knowledge and Description. Londres, Routledge.

\section{KARADIMAS, Dimitri}

2003 "Dans le corps de mon ennemi: L'Hôte parasité chez les insectes comme un modèle de reproduction chez les Mirańa d'Amazonie colombienne”. In MOTTEFlorac, É. e Thomas, J. M. C. (orgs.), Les "Insectes" dans la tradition orale: "Insects" in Oral Literature and Tradition. Paris, Peeters: pp. 487-506.

2008 "La Métamorphose de Yurupari: Flûtes, trompes et reproduction rituelle dans le nord-ouest amazonien”. Journal de la Société des Américanistes, Paris, v. 94, n. 941: $127-169$.

\section{KIRCHHOFF, Paul}

1943 "Mesoamérica, sus límites geográficos, composición étnica y carácteres culturales”. Acta Americana, México D.F., Los Angeles, v. 1: 92-107. 
KOHN, Eduardo

2007 "How Dogs Dream: Amazonian Natures and the Politics of Transspecies Engagement”. American Ethnologist, Malden/MA, v. 34, n.1: 3-24.

2013 How Forests Think. Toward an Anthropology Beyond the Human. Berkeley, University of California Press.

LAGROU, Els

2012. "Perspectivismo, animismo y quimeras: una reflexión sobre el grafismo amerindio como técnica de alteración de la percepción”. Mundo Amazonico, v. 3: $17-42$.

LEMONNIER, Pierre

2012 Mundane Objects: Materiality and Non-Verbal Communication. Walnut Creek/CA, Left Coast Press.

MAGAŃA, Edmundo

1986 Los Indios Wayana de Suriname. Amsterdam, Cedla.

MALINOWSKI, Bronislaw

1948 [1926] Magic, Science and Religion and Other Essays. Glencoe, Illinois, Free Press.

PrAET, Istvan

2013 Animism and the Question of Life. Nova York, Routledge.

Pitrou, Perig

2012 "Figuration des processus vitaux et co-activité dans la Sierra Mixe de Oaxaca (Mexique)". L'Homme, Paris, v. 202, n.2: 77-111. 
2014 "La Vie: un objet pour l'anthropologie. Options méthodologiques et problèmes épistémologiques". L'Homme, v. 212: 159-189.

2015 "Life as a Process of Making in Mixe Highlands (Oaxaca, Mexico): Towards a 'General Pragmatics' of Life”. Journal of the Royal Anthropological Institute, v. 21, n. 1: 86-105.

\section{SANTOS-GRANERO, Fernando}

1998 "Writing History into the Landscape: Space, Myth, and Ritual in Contemporary Amazonia.” American Ethnologist, Malden/MA, v. 25, n.2: 128-148.

2004 "Arawakan Sacred Landscapes. Emplaced Myths, Place Rituals, and the Production of Locality in Western Amazonia”. In HalbmaYer, E. e MAder, E. (orgs.),Kultur, Raum, Landschaft: Die Bedeutung des Raumes in Zeiten der Globalität. Frankfurt, Brandes \& Apsel, pp. 93-122.

(org.) 2009 The Occult Life of Things. Native Amazonian Theories of Materiality and Personhood. Tucson, University of Arizona Press.

2012 "Beinghood and People-Making in Native Amazonia: A constructional Approach with a Perspectival Coda”. HAU: Journal of Ethnographic Theory, v. 2, n.1: 181-211.

SEVERI, Carlo

2015 The Chimera Principle. An anthropology of Memory and Imagination. Chicago, HAU Books.

TURNER, Terence S. 2009 "The Crisis of Late Structuralism: Perspectivism and Animism: Rethinking Culture, Nature, Spirit, and Bodiliness". Tipiti: Journal of the Society for the Anthropology of Lowland South America, v. 7, n. 1: 3-40. 
UZENDOSKI, Michael A.

2012 "Beyond Orality: Textuality, Territoriality, and Ontology among Amazonian People." HAU: Journal of Ethnographic Theory, v. 2, n.1: 55-80.

UzEndOSKI, Michael e CALAPUCHA-TAPUY, Edith Felicia 2012 The Ecology of the Spoken Word: Amazonian Storytelling and Shamanism among the Napo Runa. Urbana, University of Illinois Press.

VELTHEM, Lúcia Hussak van 1992 "Das cobras e lagartas: a iconografia Wayana”. In VIDAL, L. (org.), Grafismo indígena. São Paulo, Studio Nobel/Fapesp/Edusp, pp. 53-66.

1998 A pele de Tuluperê: uma etnografia dos trançados Wayana. Belém, Pará: PR/MCT/CNPq, Museu Paraense Emilio Goeldi.

Viveiros DE CASTRO, Eduardo 1998 "Cosmological Deixis and Amerindian Perspectivism". Journal of the Royal Anthropological Institute (N.S.), Londres, v. 4, n.3: 469-488.

2012 "Immanence and Fear. Stranger-Events and Subjects in Amazonia". HAU: Journal of Ethnographic Theory, vol. 2, pp. 27-43.

WILBERT, Johannes 1974 Yukpa Folktales. Los Angeles, University of California Press. 


\section{Weaving the World and the Origins of Life as We Know It. Notions of Growth, Fabrication and Reproduction in Yukpa Origin Myths.}

ABSTRACT: This paper deals with the meaning of life among the Yukpa as depicted and verbalized in their origin myths. Yukpa myths transmit particularly conceptualized knowledge about life-processes, partly conceptualized as skilled craftsmanship, and transformations that create the conditions and forms of life as we know it. By focusing on the processes that create life as it is known today the life-processes of growing, fabricating and reproducing are identified and differentiated. It is argued that life-processes among the Yukpa go beyond a biological self-referential reproduction of different species and instrumental activities of fabrication. Life is conceptualized both spatially as continuing localized relational activity and as metamorphical cyclical transformation. From the localized perspective to leave or disappear from a relational activity are forms of dying or being born. Life in its metamorphical sense includes ongoing existence in co-existing worlds. A definite end of life will only occur if these metamorphical and cyclical transformations come to an end.

KEYWORDS: Yukpa, origin myth, life-processes, craftmanship, fabrication, growth, reproduction, life as localized relational activity, life as metamorphical cyclical transformation. 